\title{
Communication
}

\section{The Nexus between Cultural Heritage Management and the Mental Health of Urban Communities}

Dirk H. R. Spennemann (1)

Citation: Spennemann, D.H.R. The Nexus between Cultural Heritage Management and the Mental Health of Urban Communities. Land 2022, 11 304. https://doi.org/10.3390/ land11020304

Academic Editors: Thomas Panagopoulos and Anna Winiarczyk-Raźniak

Received: 28 January 2022

Accepted: 14 February 2022

Published: 16 February 2022

Publisher's Note: MDPI stays neutral with regard to jurisdictional claims in published maps and institutional affiliations.

Copyright: (C) 2022 by the author. Licensee MDPI, Basel, Switzerland. This article is an open access article distributed under the terms and conditions of the Creative Commons Attribution (CC BY) license (https:// creativecommons.org/licenses/by/ $4.0 /)$.
School of Agricultural, Environmental and Veterinary Sciences, Charles Sturt University, P.O. Box 789, Albury, NSW 2640, Australia; dspennemann@csu.edu.au

\begin{abstract}
In authorized cultural heritage management discourse, heritage sites can be included in local government heritage registers if their aesthetic, scientific, historic or social values are deemed significant. While notionally providing protection from major alterations and destruction for the benefit of future generations, such listings primarily serve the present generation whose values they reflect. This paper considers the role that cultural heritage places play in terms of community identity and their contribution to a sense of place, to place attachment and, by implication, to personal and community mental health.
\end{abstract}

Keywords: cultural heritage policy; cultural heritage management; community health; mental health; urban sociology

\section{Introduction}

In broad terms, cultural heritage is the result of peoples' interactions, both among themselves and with the environment in which they live. The outcome of these processes manifests itself in a number of forms. Peoples' interactions with each other result in intangible cultural heritage which finds its expression, inter alia, in language, folklore, skills and customs, whereas peoples' interaction with the environment manifests itself in tangible form, such as the built environment, cultural landscapes, resource extraction and refuse sites, as well as in moveable objects and artefacts. Heritage places, together with places that hold items of heritage association, such as museums and art galleries, make up part of the cultural fabric of any society [1-3].

The values that underpin cultural heritage are anthropogenic projections on to cultural practices (e.g., song, ritual, performance) [4], as well as on to inanimate entities, be they anthropogenically generated (e.g., objects, sites, buildings) or natural spaces (e.g., landscape features imbued with community relevance; eco-cultural heritage). Formed during a person's upbringing, these values are modulated by individual life-experiences, by cultural conditioning due to a person's enmeshing in the local community and the wider society, and by external stimuli acquired through interpersonal relationships, through communication (e.g., news items, literature) or through travel. These values are not only personal and individual, but they are also not static. Rather, they are mutable qualities both because the valuing individual ages and due to changes to cultural and societal influences acting on the valuer [5]. Collectively, the congruence of individual values at any given time generates community values with regard to cultural practices and cultural heritage sites in local communities.

These practices and sites, if deemed 'significant,' tend to be codified in what has been termed 'authorized cultural heritage management discourse,' through listings and other protective instruments and processes [6,7]. Subsequently, some heritage places, such as those on which World Heritage status has been bestowed as an imprimatur of 'universal cultural value,' have been monetized by becoming foci of cultural and heritage tourism $[8,9]$.

The aim of this conceptual communication is to explore the notion that heritage places are important for a community's well-being and individual personal mental health and, in 
consequence, to make a case for including cultural heritage places and practices as part of the social policy tool kit of communities. This paper is based on a theoretical exploration and deliberation rather than empirical data. Following an examination of the dissonance between public perceptions of formalized heritage values versus the perception of nostalgia, this paper will consider aspects of place theory to demonstrate the role of heritage in the emotional well-being of the community.

\section{Heritage Values and Nostalgia}

From its early beginnings at the end of the nineteenth century, heritage preservation has struggled with the notions of heritage value and how such values should be defined. In his seminal 1903 work "Der moderne Denkmalkultus: sein Wesen und seine Entstehung" the Austrian art historian Alois Riegl discussed four heritage related values, age value (Alterswert), historic value (historischer Wert) and designed memory value ('gewollter Erinnerungswert') and aesthetic value ('Kunstwert') [10].

As the heritage profession 'matured,' the theoretical underpinnings of heritage value were increasingly dissected and categorized under the umbrellas of aesthetic, scientific, historic, and (in Australia) social value. These were then canonized in the U.S. Secretary of the Interior's standards for rehabilitation and guidelines for rehabilitating historic buildings [11-13], ICOMOS Charters such as the Venice Charter [14] and the Burra Charter [15-19], associated practice notes [20,21] and heritage guidelines [22]. At the same time, the attribute of mere age/antiquity was discarded as a characteristic of heritage. Older concepts of memory value, whether designed (e.g., monuments) or organically generated (e.g., sites and buildings) were likewise disregarded, unless the memory value of site/place/object could be subsumed under the categories of historic value or social value. It has been recognized that this categorization and canonization of values has limitations, because the boundaries between the value fields are fluid and overlapping and because heritage value typologies are ill defined [23]. Increasingly, heritage evaluations were carried out, and dominated, by experts, i.e., archaeologists, historians, historic architects and landscape architects [2,7,24,25].

While the formal, authorized heritage management discourse has focused on the collective manifestation and interpretation of values, heritage remains as an inherently personal and often very emotive concept. Heritage is contributory, if not central to people's identity. As community heritage studies have shown, the general public is less concerned with the heritage values as defined in the authorized heritage management discourse and applies their own personal projections. These are a combination of respect for the age and antiquity of a place, for the aesthetic value that a place holds and for a sense and longing for times gone by, the latter readily summarized under the heading of nostalgia [26,27].

While downplayed, if not denigrated, by the authorized heritage management discourse $[28,29]$, nostalgia, the sentimental and melancholic desire and longing for a past as enshrined in personal memory [30], has been identified as a major driver of heritage tourism [31-34]. Significantly, the notions of heritage and nostalgia are often focused on places and spaces, with their associated natural or built environment, rather than isolated objects or structures [26,27].

\section{Connection to Place as a Sense of Community Well-Being}

Psychologically, we tend to seek out the familiar in our physical environment, thereby creating a personal, emotional attachment to a place, be it a landscape, a town, or a feature in a town, such as a streetscape or a single building [35]. A considerable body of research has examined the nature and extent of personal attachment to a place coming from disciplines as varied as environmental psychology, anthropology, sociology, linguistics and human geography, as well as mental and allied health [36-40]. An attachment to place has been described as "a positive affective association between individuals and their residential environments, an association that creates feelings of comfort and security" [39]. The experiences that result from that positive affective association and interaction, combined 
with concepts of identity, evoke in people a sense of place $[37,38]$. Through personal attachment to a physical place, a person can acquire a sense of belonging and purpose in that place. The merger of individual personality with a place creates place identity, which in turn gives meaning to life in that community [41]. Rootedness, on the other hand describes a temporal concept within which a strong attachment or bond to a place has developed over time [37].

That heritage contributes to community and personal identity and adds to a community's social life is a universal perception, expressed by urban $[42,43]$ as well as rural communities [44,45]. As outlined in a discussion paper for the Council of Europe, heritage matters to a person and a community, because "it is part of our quality of life" through shaping places, cultural identity and memory, and by providing amenity values to the community [46]. Furthermore, the paper argues, that "cultural heritage ... has the potential to contribute to social cohesion and democratic citizenship" primarily due to its importance "in defining a sense of identity, of belonging to a community, a place, a region" [46].

Not surprisingly, then, heritage aspects have been drawn on to aid modern-day placemaking and community revitalization efforts [47]. The European Cultural Heritage Green paper, for example, argues that "cultural heritage can be a catalyst for positive change, as it has the power to connect people to places, encourage a sense of belonging and foster social inclusion [48]".

\section{Role of Familiar Places/Heritage/Landmarks in Disaster Recovery}

Given the connection between a sense of rootedness and belonging and the resultant attachment to a physical setting or place, it is not surprising that heritage places are no longer valued once a community feels disconnected from the meaning of the place. Conversely, it can be posited that the community may suffer, if the heritage fabric of those places that are valued and contribute to a community's identity and sense of place is damaged or destroyed [3,49].

This can be demonstrated in communities that have been displaced or were forced to relocate, be it due to infrastructure developments, such as the construction of dams flooding the valleys in which the villages were established [50-53], the shutdown of dominant industries [54], or due to environmental change. In these cases the disappearance of familiar cultural markers from the physical environment creates a diminution, if not loss, of a sense of place and identity [50], which on occasion has been addressed as solastalgia [52].

In the same vein, the loss of "place" as a result of the widespread destruction in the wake of natural disasters (cyclones/hurricanes, volcanic eruptions, earthquakes) [55] or large-scale urban 'renewal' [56] has been linked to negative psychological impacts experienced by many citizens and thus ultimately to a decline of community mental health [52]. Conversely, those communities tend to recover faster from natural disasters [57] where the key features of their cultural environment, the iconographic buildings and sites have not been destroyed, or where places associated with tangible and intangible heritage are quickly restored [58]. Damaged places that cannot be speedily repaired due to structural, financial, or administrative constraints tend to function as festering sores, acting as constant reminders of the events and loss.

The aftermath of the large-scale devastation of many urban centers as a result of aerial bombardment during World War II provides a further, potent, example. Where the destruction was seen as an opportunity for urban modernization and redesign, it caused the loss of a sense of place, often resulting in spaces that were perceived as alienating [59-61]. The numerous efforts at the restoration of civic spaces had positive effects and resulted in a concomitant 'healing' of civic communities. Examples with positive, albeit occasionally contested [62,63], outcomes are Warsaw [64], Gdansk [60], Malta [65], Dresden [66], Frankfurt [67], Rothenburg [68], and Sewastopol [69]. 
This observation has led to calls not only to ensure that disaster management plans are drawn up for historic properties but, moreover, to consider historic properties as part of a community's critical infrastructure and thus form an integral part of disaster responses and post-disaster recovery $[70,71]$.

\section{Community Mental Health in an Age of Globally Accelerating Change}

Many countries are faced with ageing populations [72,73], with a concomitantly increasing demand for physical and mental health services [74]. As people age, the need for connection with familiar landmarks increases, both as emotional anchors and, on a more basic level, as makers to navigate their spatial environment $[75,76]$. In many communities, concepts of ageing in place have been advocated to allow people to maintain their connections to their neighborhoods [76-78].

It is important not to underestimate the role played by cultural institutions, such as museums and art galleries not only in the cultural lives of older citizens [79-81] but through their inclusiveness [82] and in their contribution to people's sense of self-worth and even physical health $[83,84]$. Recent studies suggest that museums and art galleries can also serve as tools to improve the mental health of younger people [85].

\section{Lessons from the COVID-19 Pandemic}

The COVID-19 pandemic created a social experiment on a local, national and even global scale that would never have been sanctioned by ethics review boards of academic institutions: a wholesale restriction of people's movement through stay-at-home orders ('lockdown'); enforced social distancing; prohibition of communal gatherings at festivals, sporting events and religious services; and exclusion of people from 'non-essential' services, including retail shops, museums and libraries.

Social venues, whether they were formal in the form of community centers or informal in the form of street cafés, ceased to function. Public spaces in plazas and town squares became 'no lingering' zones, denying the community the opportunity to rest and reflect in familiar outdoor surroundings.

While engaging in physical exercise outdoors was permissible during lockdown periods, one of the main concerns was illicit socializing while outdoors, with the inherent risk of social distancing not being observed. The traditional function of small neighborhood/pocket parks is to provide urban green spaces as a venue for neighborhood exchange and communication and to provide an opportunity for small children to recreate in playgrounds. While in larger parks ad hoc social distancing circles could be established, some community authorities closed the smaller pocket and neighborhood parks due to perceived or actual crowding when these parks served as proxy social venues [86-88].

Not surprisingly, then, the enforced prolonged periods indoors, coupled with people's socializing being limited to video-conferencing and phone calls, caused social isolation [89]. During the lockdown period many people experienced a higher level of psychological stressors, both in frequency and intensity, leading to potentially harmful interpersonal and environmental stimuli, including domestic violence and abuse, as well as deteriorating family relationships $[89,90]$. Sections of the community, such as older people, people with poor mental health, people with disability, people with non-communicable diseases, people who were homeless, people living on their own, and people with reduced communication and limited social networks beyond their work settings, were disproportionately at risk $[90,91]$, with the pandemic both exacerbating existing mental health conditions [91-94] and creating and intensifying inequalities [89,94-97].

The cross-sectorial disruptor represented by COVID-19 has highlighted the fragility of the consumptive aspects of cultural heritage, in particular cultural tourism [98], museum visits [79], auditory heritage [99,100], festivals [101,102] and community events [102] as well as seasonal markets [103]. While several cultural tourism localities and cultural institutions swiftly pivoted to various forms of virtual delivery [104-107] touting it as the new dawn, this pivot marginalized some segments of society [108]. Indeed, many intangible aspects of 
heritage, in particular those that rely on multisensorial experiences could not be replicated fully and could only be substituted in rudimentary form [103]. While the pivot to digital delivery suited the younger, 'techno- and future-native' generations, many seniors, even 'future-migrants' [109], found them unfulfilling and challenging [79]. At the same time, the restrictions on human movement imposed by the public health orders in response to COVID-19 created a sense of nostalgia for experiences gained in the pre-pandemic days, with increased demand expressed for cultural tourism [31].

\section{Past, Present and Future Heritage Processes}

In the past, heritage assessment and planning processes, as part of the authorized discourse, were predominantly expert-driven and the sole domain of heritage management professionals - primarily dominated by architects, historians and archaeologists [110], drawing up local government heritage registers as well as site-specific conservation management plans [111]. The cultural values that could be drawn on for the assessment of the significance of places from protection were informed, and dominated, by expert opinion: aesthetic value, scientific value and historic value [12-14].

Today, community-wide heritage assessment and planning processes tend to be more inclusive or even primarily driven by community representation with the experts often relegated to coordinating and facilitating roles [24]. Significantly, the value of heritage places to a community can be recognized in some jurisdictions in the form of social value $[17,112,113]$ but this can still exclude marginalised communities even though they may have strong attachment to place [114]. There have been criticisms about the fact that community perceptions of heritage tend to be colored by nostalgia and adverse for dissonance [114]. Nonetheless, it is this nostalgia, comfort and inclusiveness that creates the sense of place and thus supports individual mental health and community resilience in the face of adversity or fundamental change [115].

While a comprehensive architecture for a suite of conservation management plans exists [116], realities of limited funding, primarily staff time, result in less than ideal outcomes, with some components, such as conservation management plans, disaster management plans, and public interpretation strategies/plans regularly not completed or inadequately executed $[117,118]$. In most cases, heritage agencies and sections of local government tasked with the preservation of heritage are resource poor and thus stretched to cover their mandates, let alone conduct or have close oversight over such projects.

Heritage assessment and planning processes appear to cater to the select segments of society, driven by heritage management professionals or by, generally older, self-motivated community members who tend to have the time and inclination to participate in community meetings $[24,119]$. Since social scientists are rare among the heritage management professionals involved in the planning processes, few studies employ formal surveys to consider the views of the silent majority of the general public - those who are interested in the outcomes, but who are too time poor to provide in-person participation at community consultation events. Yet such studies not only provide a much richer and more diverse response, but also allow a community-wide degree of attachment to specific properties to be assessed, be they chosen from a predefined list or (ideally) self-nominated $[24,119,120]$.

The general rhetoric among heritage professionals postulates the notion of the preservation of cultural heritage places primarily for the benefit of future generations [121-123]. The reality of the matter is that we are preserving heritage items for the use and benefit of the present generation $[3,124]$. At the same time, the present generation foists its own views upon the next by using its own values to selectively protect items deemed worthy of attention [3].

Local government heritage registers tend to be cumulative, with each new, often generational study identifying additional places to be preserved and protected. The common argument put forward for continual additions is to ensure that heritage lists are 'comprehensive'. In consequence, unless destroyed or irreparably damaged due to neglect, natural 
or technological disasters or to demolition, once included, the items tend to remain on this listing, seemingly in perpetuity.

As cultural values held by a community are mutable qualities, it needs to be appreciated that the community perception as to what does, and what does not, comprise heritage worth preserving will change. Nonetheless, heritage items listed in local government heritage registers are canonized in their value as heritage, although these values were attributed by a past generation and may no longer reflect the perceptions of the present or withstand modern scrutiny of past evaluation processes. A continually additive process potentially creates bloated heritage registers of questionable validity, while at the same time diluting a local government's capacity for effective managerial oversight and active protection. The latter is most insidious, as ill-considered permitting decisions, for example, can establish precedents with unintended and unanticipated consequences. In addition, perpetuating the listing of items whose cultural heritage value is no longer given, poses an impost on the property owners, who may be unnecessarily and unduly constrained in their actions.

As has been argued by numerous authors, for heritage items to be sustainable in the present environment, they have to be functional entities [125]. Not all heritage objects, practices and places, however, can be maintained and unchanged in form and function, primarily due to technological change that leads to loss of function or even obsolescence. While objects can be collected, and practices can be documented, structures occupy space, which in urban centers is at a premium. Thus, unless adaptive reuse options can be found that change the function of a structure but leave it externally unchanged, but often with substantive alterations [126], a structure will transition from a potential community asset to a liability. The question arises, whether the loss of a given heritage-listed structure matters, and if so, to whom?

If local government heritage registers are regarded merely as outcomes and manifestations of administrative processes engaged in by a select few, rather than as true reflections of community identity and community values, including the mental-health affirming nostalgia, then the community will become disengaged and the loss of a given heritage-listed structure often will not matter at all. At the same time, however, this then can establish a precedent, which when repeated, devalues the meaning of heritage listings altogether.

\section{Outlook}

The fundamental question to be answered when considering local government heritage registers is for whom heritage should be preserved. For the community at large, or for a select few formally recognized or self-appointed experts? There is a need for methodologically rigorous, social science-driven assessments of a community's cultural and historical identity, and for true community-wide determinations of those heritage items in the urban environment that substantively contribute to a sense of place and place attachment. It is these places that contribute to the mental health and well-being of individuals and the community at large.

This is not carte blanche for majority rule, however. There will always be a need for external expert review to ensure the inclusion of the heritage of minorities, of dissonant and 'dark' heritage, and of arcane, yet highly significant scientific, architectural or historic examples. While they need to be included and prominently discussed, these, however, should not dominate. While the latter may be canonized in their protection, the remainder needs to be dynamic, reflecting the community at large for whom that heritage serves. If this can be achieved, then heritage management can become an integral part of social policy and effectively contribute to community mental health.

Funding: This research received no external funding.

Data Availability Statement: Not applicable.

Conflicts of Interest: The author declares no conflict of interest. 


\section{References}

1. Sandell, R. Museums as agents of social inclusion. Mus. Manag. Curatorship 1998, 17, 401-418. [CrossRef]

2. Smith, L. Uses of Heritage; Routledge: Abingdon, UK, 2006.

3. Spennemann, D.H.R. Beyond "Preserving the Past for the Future": Contemporary Relevance and Historic Preservation. CRM J. Herit. Steward. 2011, 8, 7-22.

4. Del Barrio, M.J.; Devesa, M.; Herrero, L.C. Evaluating intangible cultural heritage: The case of cultural festivals. City Cult. Soc. 2012, 3, 235-244. [CrossRef]

5. de la Torre, M. Values and heritage conservation. Herit. Soc. 2013, 6, 155-166. [CrossRef]

6. Högberg, A. The Voice of the Authorized Heritage Discourse: A critical analysis of signs at ancient monuments in SKåne, southern Sweden. Curr. Swed. Archaeol. 2013, 20, 131-167. [CrossRef]

7. Smith, L.; Waterton, E. Constrained by commonsense: The authorized heritage discourse in contemporary debates. Oxf. Handb. Public Archaeol. 2012, 153-171.

8. McCormick, R.R. Marketing Cultural and Heritage Tourism: A World of Opportunity; Routledge: London, UK, 2016.

9. Teo, C.B.C.; Khan, N.R.M.; Rahim, F.H.A. Understanding Cultural Heritage Visitor Behavior: The Case of Melaka as World Heritage City. Procedia-Soc. Behav. Sci. 2014, 130, 1-10. [CrossRef]

10. Riegl, A. Der Moderne Denkmalkultus: Sein Wesen und Seine Entstehung; W.Braumüller: Wien, Austria; Leipzig, Germany, 1903.

11. Hume, G.L. The Secretary of the Interior's Standards for Rehabilitation and Guidelines for Rehabilitating Historic Buildings; US Department of the Interior, National Park Service, Preservation Assistanec Divsin: Washington, DC, USA, 1983.

12. U.S. Department of the Interior. The Secretary of the Interior's Standards for Rehabilitation and Guidelines for Rehabilitating Historic Buildings (36 CFR 67); Preservation Assistance Division, National Park Service, U.S. Department of the Interior: Washington, DC, USA, 1990.

13. U.S. Department of the Interior. The Secretary of the Interior's Standards for Rehabilitation and Guidelines for Rehabilitating Historic Buildings (36 CFR 67); Technical Preservation Services, National Park Service, U.S. Department of the Interior: Washington, DC, USA, 2011.

14. ICOMOS. International Charter for the conservation and restoration of monuments and sites. In Proceedings of the First Developed at the 2nd International Congress of Architects and Technicians of Historic Monuments, Venice, Italy, 25-31 May 1964; International Council of Monuments and Sites: Venice, Italy, 1964.

15. Australia ICOMOS. The Australia ICOMOS Guidelines for the Conservation of Places of Cultural Significance ("Burra Charter"); Australia ICOMOS Inc.: Burwood, VIC, Australia, 1979.

16. Australia ICOMOS. The Burra Charter. The Australia ICOMOS Charter for Places of Cultural Significance 1999 with Associated Guidelines and Code on the Ethics of Co-Existence; Australia ICOMOS Inc., International Council of Monuments and Sites: Burwood, VIC, Australia, 2000.

17. Australia ICOMOS. The Burra Charter. The Australia ICOMOS Charter for Places of Cultural Significance 2013; Australia ICOMOS Inc., International Council of Monuments and Sites: Burwood, VIC, Australia, 2013.

18. Walker, M. The development of the Australia ICOMOS Burra charter. APT Bull. J. Preserv. Technol. 2014, 45, 9-16.

19. Hannah, B. Innovation in Conservation: A Timeline History of Australia ICOMOS and the Burra Charter Technical Report; Australia ICOMOS: Burwood, VIC, Australia, 2017.

20. Australia ICOMOS. Understanding and Assessing Cultural Significance [Practice Note]; Australia ICOMOS Inc., International Council of Monuments and Sites: Burwood, VIC, Australia, 2013.

21. Marquis-Kyle, P.; Walker, M. The Illustrated Burra Charter: Making Good Decisions about the Care of Important Places; Australian Heritage Commission: Sydney, NSW, Australia, 1994.

22. NSW Heritage Office (Ed.) Local Government Heritage Guidelines; NSW Heritage Office: Sydney, NSW, Australia, 2002.

23. Fredheim, L.H.; Khalaf, M. The significance of values: Heritage value typologies re-examined. Int. J. Her. Stud. 2016, $22,466-481$. [CrossRef]

24. Spennemann, D.H.R. Your solution, their problem. Their solution, your problem: The Gordian Knot of Cultural Heritage Planning and Management at the Local Government Level. DisP-Plan. Rev. 2006, 42, 30-40. [CrossRef]

25. Silberman, N. Changing visions of heritage value: What role should the experts play? Ethnologies 2014, 36, 433-445. [CrossRef]

26. Yeoh, B.; Kong, L. The notion of place in the construction of history, nostalgia and heritage in Singapore. Singap. J. Trop. Geogr. 1996, 17, 52-65. [CrossRef]

27. Arboleda, P.; Lorimer, H. Notes from a shrinking market: 'Anticipatory nostalgia' and place-making in the midst of change. In Geographies of Post-Industrial Place, Memory, and Heritage; Routledge: Abingdon, UK, 2020; pp. 23-36.

28. Lowenthal, D. The Past Is a Foreign Country; Cambridge University Press: Cambridge, UK, 1985.

29. Lowenthal, D. The Past Is a Foreign Country-Revisited; Cambridge University Press: Cambridge, UK, 2015.

30. Pickering, M.; Keightley, E. The modalities of nostalgia. Curr. Sociol. 2006, 54, 919-941. [CrossRef]

31. Chark, R. Midnight in Paris: On heritage and nostalgia. Ann. Tour. Res. 2021, 90, 103266.

32. Goulding, C. Heritage, nostalgia, and the "grey" consumer. J. Mark. Pract. Appl. Mark. Sci. 1999, 5, 177-199. [CrossRef]

33. Ali, F. Heritage tourist experience, nostalgia, and behavioural intentions. Anatolia 2015, 26, 472-475. [CrossRef]

34. Gao, J.; Lin, S.S.; Zhang, C. Authenticity, involvement, and nostalgia: Understanding visitor satisfaction with an adaptive reuse heritage site in urban China. J. Destin. Mark. Manag. 2020, 15, 100404. 
35. Fried, M. Continuities and discontinuities of place. J. Environ. Psychol. 2000, 20, 193-205. [CrossRef]

36. Tuan, Y.F. Language and the making of place: A narrative-descriptive approach. Ann. Assoc. Am. Geogr. 1991, 81, 684-696. [CrossRef]

37. Hay, R. Sense of place in developmental context. J. Environ. Psychol. 1998, 18, 5-29. [CrossRef]

38. Australian Heritage Commission. A Sense of Place? A Conversation in Three Cultures; Australian Heritage Commission: Canbera, ACT, Australia, 1989.

39. McAndrew, F.T. The Measurement of 'Rootedness' and the Prediction of Attachment to Home-Towns In College Students. J. Environ. Psychol. 1998, 18, 409-417. [CrossRef]

40. Tuan, Y.-F. Place: An experiential perspective. Geogr. Rev. 1975, 65, 151-165. [CrossRef]

41. Proshansky, H.M.; Fabian, A.K.; Kaminoff, R. Place-identity: Physical world socialization of the self. J. Environ. Psychol. 1983, 3 , 57-83. [CrossRef]

42. Hawke, S.K. Sense of place in changing communities: The plurality of heritage values. In Proceedings of the ICOMOS Scientific Symposium Dublin Castle, Dublin, Ireland, 30 October 2010; p. 37.

43. Han, K.; Shih, P.C.; Rosson, M.B.; Carroll, J.M. Enhancing community awareness of and participation in local heritage with a mobile application. In Proceedings of the 17th ACM Conference on Computer Supported Cooperative Work \& Social Computing, Baltimore, MD, USA, 15-19 February 2014; pp. 1144-1155.

44. Spennemann, D.H.R.; Harris, K. Cultural Heritage of Culcairn Shire. Some Considerations for Strategic Planning; The Johnstone Centre, Charles Sturt University: Albury, NSW, Australia, 1996; Volume 71.

45. Hawke, S.K. Local residents exploring heritage in the North Pennines of England: Sense of place and social sustainability. Int. J. Herit. Sustain. Dev. 2011, 1, 32-40.

46. Council of Europe. Forward Planning: The Function of Cultural Heritage in a Changing Europe; The Council of Europe: Strasbourg, France, 2002.

47. Pendlebury, J.; Porfyriou, H. Heritage, Urban Regeneration and Place-Making. J. Urban Des. 2017, 22, 429-432. [CrossRef]

48. Potts, A. European Cultural Heritage Green Paper. Putting Europe's Shared Heritage at the Heart of the European Green Deal; Europa Nostra: Hague, The Netherlands; Brussles, Belgium, 2021.

49. Hull, R.B.; Lam, M.; Vigo, G. Place identity: Symbols of self in the urban fabric. Landsc. Urban Plann. 1994, 28, 109-120. [CrossRef]

50. Read, P. Returning to Nothing: The Meaning of Lost Places; Cambridge University Press: Melbourne, VIC, Australia, 1996.

51. Landy, D. Tallangatta tomorrow. Gov. News 2013, 33, 26-29.

52. Albrecht, G. 'Solastalgia'. A new concept in health and identity. PAN Philos. Act. Nat. 2005, 41-55.

53. Read, P. Our lost drowned town in the valley, perceptions of the inundation of Adaminaby, 1956-1957. Public Hist. Rev. 1992, $1,160-174$.

54. Scott, C. Contemporary expressions of coal mining heritage in the Durham Coalfield: The creation of new identities. Folk Life 2009, 47, 66-75. [CrossRef]

55. Raphael, B. When Disaster Strikes: A Handbook for the Caring Professions; Hutchinson: London, UK, 1986.

56. Harun, N.Z.; Mansor, M.; Said, I. Place rootedness suggesting the loss and survival of historical public spaces. Procedia Environ. Sci. 2015, 28, 528-537. [CrossRef]

57. Historic Preservation Division. After the Flood: Rebuild-Ing Communities through Historic Preservation; Historic Preservation Division and Georgia Department of Natural Resources: Atlanta, GA, USA, 1997.

58. $\mathrm{Wu}, \mathrm{H}$.; Hou, C. Utilizing co-design approach to identify various stakeholders' roles in the protection of intangible place-making heritage: The case of Guchengping Village. Disaster Prev. Manag. Int. J. 2019, 29, 22-35. [CrossRef]

59. Diefendorf, J.M. In the Wake of War: The Reconstruction of German Cities after World War II; Oxford University Press: Oxford, UK, 1993.

60. Jeleński, T. Practices of Built Heritage Post-Disaster Reconstruction for Resilient Cities. Buildings 2018, 8, 53. [CrossRef]

61. Musiaka, Ł.; Figlus, T.; Szmytkie, R. Models of morphological transformations of centres of the largest Polish cities after World War II. Eur. Plan. Stud. 2021, 29, 511-535.

62. Schediwy, R. Rekonstruktion. Wiedergewonnenes Erbe Oder Nutzloser Kitsch? LIT-Verlag: Münster, Germany, 2011.

63. Fischer, L. Robert Schediwy, Rekonstruktion. Wiedergewonnenes Erbe oder nutzloser Kitsch? Burgen Schlösser-Z. Burgenforschung Denkmalpfl. 2012, 53, 130.

64. Hołuj, D. Public Spaces and Cultural Heritage in Community Projects-the Example of Warsaw. Eur. Spat. Res. Policy 2017, 24, 127-144. [CrossRef]

65. Ashworth, G.J.; Tunbridge, J.E. Multiple approaches to heritage in urban regeneration: The case of City Gate, Valletta. J. Urban Des. 2017, 22, 494-501. [CrossRef]

66. Danilović Hristić, N.; Stefanović, N. The Rebuilding of Memory Through Architecture-Case Studies of Leipzig and Dresden. J. Urban Cult. Res. 2020, 20, 97-111.

67. Sturm, P.; Cachola Schmal, P. Die Immer Neue Altstadt; Forever New: Frankfurt's Old Town Bauen Zwischen Dom und Römer Seit 1900; Jovis: Frankfurt, Germany, 2018.

68. Hagen, J. Rebuilding the Middle Ages after the Second World War: The cultural politics of reconstruction in Rothenburg ob der Tauber, Germany. J. Hist. Geogr. 2005, 31, 94-112. 
69. Qualls, K.D. From Ruins to Reconstruction: Urban Identity in Soviet Sevastopol after World War II; Cornell University Press: Ithaca, NY, USA, 2009.

70. Spennemann, D.H.R.; Look, D.W. From Conflict to dialogue, from dialogue to cooperation, from cooperation to preservation. In Disaster Management Programs for Historic Sites; Spennemann, D.H.R., Look, D.W., Eds.; Western Chapter, Association for Preservation Technolog: San Francisco, CA, USA; Johnstone Centre, Charles Sturt University: Albury, NSW, Australia, 1998; pp. 175-188.

71. Spennemann, D.H.R.; Graham, K. The importance of heritage preservation in natural disaster situations. Int. J. Risk Assess. Manag. 2007, 7, 993-1001. [CrossRef]

72. Eurostat. Ageing Europe-Looking at the Lives of Older People in the EU. Available online: https:/ / ec.europa.eu/eurostat/ documents /3217494/11478057/KS-02-20-655-EN-N.pdf (accessed on 1 February 2022).

73. McDonald, P. Ageing in Australia: Population changes and responses. Popul. Ageing 2016, 65, 1-20.

74. Beard, H.P.J.R.; Bloom, D.E. Towards a comprehensive public health response to population ageing. Lancet 2015, $385,658$. [CrossRef]

75. Musselwhite, C. Creating a convivial public realm for an ageing population. Being a pedestrian and the built environment. In Transport, Travel and Later Life; Emerald Publishing Limited: Bingley, UK, 2017.

76. Li, X.; Zhang, T. Place identity and older residents' coping strategies while ageing in declining neighbourhoods of urban China. J. Environ. Psychol. 2021, 78, 101692. [CrossRef]

77. Stafford, P.B. Elderburbia: Aging with a Sense of Place in America: Aging with a Sense of Place in America; ABC-CLIO: Santa Barbara, CA, USA, 2009.

78. Winterton, R.; Warburton, J. Ageing in the bush: The role of rural places in maintaining identity for long term rural residents and retirement migrants in north-east Victoria, Australia. J. Rural Stud. 2012, 28, 329-337. [CrossRef]

79. Presti, O.L. COVID-19 and the cultural life of older people. Mus. Manag. Curatorship 2021, 1-11. [CrossRef]

80. Thomson, L.J.; Chatterjee, H.J. Measuring the impact of museum activities on well-being: Developing the Museum Well-being Measures Toolkit. Mus. Manag. Curatorship 2015, 30, 44-62. [CrossRef]

81. Thomson, L.; Chatterjee, H. Assessing well-being outcomes for arts and heritage activities: Development of a Museum Well-being Measures toolkit. J. Appl. Arts Health 2014, 5, 29-50. [CrossRef]

82. Sandell, R. Social inclusion, the museum and the dynamics of sectoral change. Mus. Soc. 2003, 1, 45-62.

83. Bønnelycke, J.; Grabowski, D.; Christensen, J.H.; Bentsen, P.; Jespersen, A.P. Health, fun and ontonorms: Museums promoting health and physical activity. Mus. Manag. Curatorship 2021, 36, 286-302. [CrossRef]

84. O'Neill, J. How Creative Aging Programs Are Carrying on through COVID-19. Available online: https://www.aam-us.org/2020 /03/20/how-creative-aging-programs-are-carrying-on-through-covid-19/ (accessed on 15 October 2021).

85. Sheriff, R.S.; Vuorre, M.; Riga, E.; Przybylski, A.K.; Adams, H.; Harmer, C.J.; Geddes, J.R. A Cultural Experience to support Mental Health in People Aged 16-24 during COVID-19 Compared to a Typical Museum Website: Study Protocol of an Online Randomised Controlled Trial. Trials 2021, 22, 482. [CrossRef]

86. Scott, R.P. Shared streets, park closures and environmental justice during a pandemic emergency in Denver, Colorado. J. Transp. Health 2021, 21, 101075. [CrossRef]

87. Lopez, B.; Kennedy, C.; McPhearson, T. Parks are Critical Urban Infrastructure: Perception and Use of Urban Green Spaces in NYC During COVID-19. Preprints 2020, 2020080620. [CrossRef]

88. Larcher, F.; Pomatto, E.; Battisti, L.; Gullino, P.; Devecchi, M. Perceptions of Urban Green Areas during the Social Distancing Period for COVID-19 Containment in Italy. Horticulturae 2021, 7, 55. [CrossRef]

89. Grant, R.; Gorman-Murray, A.; Briohny Walker, B. The Spatial Impacts of COVID-19 restrictions on LGBTIQ wellbeing, visibility, and belonging in Tasmania, Australia. J. Homosex. 2021, 68, 647-662. [CrossRef]

90. Douglas, M.; Katikireddi, S.V.; Taulbut, M.; McKee, M.; McCartney, G. Mitigating the wider health effects of COVID-19 pandemic response. BMJ 2020, 369, m1557. [CrossRef]

91. Bil, J.S.; Buława, B.; Świerzawski, J. Mental Health and the City in the Post-COVID-19 Era. Sustainability 2021, 13, 7533. [CrossRef]

92. Pouso, S.; Borja, Á.; Fleming, L.E.; Gómez-Baggethun, E.; White, M.P.; Uyarra, M.C. Contact with blue-green spaces during the COVID-19 pandemic lockdown beneficial for mental health. Sci. Total Environ. 2021, 756, 143984.

93. Heo, S.; Desai, M.U.; Lowe, S.R.; Bell, M.L. Impact of Changed Use of Greenspace during COVID-19 Pandemic on Depression and Anxiety. Int. J. Environ. Res. Public Health 2021, 18, 5842. [CrossRef] [PubMed]

94. Ettman, C.K.; Abdalla, S.M.; Cohen, G.H.; Sampson, L.; Vivier, P.M.; Galea, S. Prevalence of Depression Symptoms in US Adults Before and During the COVID-19 Pandemic. JAMA Netw. Open 2020, 3, e2019686. [CrossRef] [PubMed]

95. Geary, R.S.; Wheeler, B.; Lovell, R.; Jepson, R.; Hunter, R.; Rodgers, S. A call to action: Improving urban green spaces to reduce health inequalities exacerbated by COVID-19. Prev. Med. 2021, 145, 106425. [CrossRef] [PubMed]

96. Alizadehtazi, B.; Tangtrakul, K.; Woerdeman, S.; Gussenhoven, A.; Mostafavi, N.; Montalto, F.A. Urban Park Usage During the COVID-19 Pandemic. J. Extrem. Events 2020, 7, 2150008. [CrossRef]

97. Uchiyama, Y.; Kohsaka, R. Access and use of green areas during the COVID-19 pandemic: Green infrastructure management in the "new normal". Sustainability 2020, 12, 9842. [CrossRef]

98. Flew, T.; Kirkwood, K. The impact of COVID-19 on cultural tourism: Art, culture and communication in four regional sites of Queensland, Australia. Media Int. Aust. 2021, 178, 16-20. [CrossRef] 
99. Spennemann, D.H.R.; Parker, M. Hitting the 'Pause' Button: What does COVID tell us about the future of heritage sounds? Noise Mapp. 2020, 7, 265-275. [CrossRef]

100. Parker, M.; Spennemann, D.H.R. Anthropause on audio: The effects of COVID-19 pandemic on church bell ringing in New South Wales (Australia). J. Acoust. Soc. Am. 2020, 148, 3102. [CrossRef] [PubMed]

101. Matzanos, D.; Xanthacou, Y. Cultural Sustainability through COVID 19: A Case Study of the Festivals on the Island of Rhodes. IJASOS-Int. E-J. Adv. Soc. Sci. 2021, 7, 153-159.

102. Mohanty, P.; Dhoundiyal, H.; Choudhury, R. Events tourism in the eye of the COVID-19 storm: Impacts and implications. In Event Tourism in Asian Countries: Challenges and Prospects, 1st ed.; Apple Academic Press: Palm Bay, FL, USA, 2020.

103. Parker, M.; Spennemann, D.H.R. Stille Nacht: COVID and the ghost of Christmas 2020. Heritage 2021, 4, 3081-3097. [CrossRef]

104. Agostino, D.; Arnaboldi, M.; Lampis, A. Italian state museums during the COVID-19 crisis: From onsite closure to online openness. Mus. Manag. Curatorship 2020, 35, 362-372. [CrossRef]

105. King, E.; Smith, M.P.; Wilson, P.F.; Williams, M.A. Digital Responses of UK Museum Exhibitions to the COVID-19 Crisis, March-June 2020. Curator Mus. J. 2021, 64, 487-504. [CrossRef]

106. Zollinger, R. Being for Somebody: Museum Inclusion During COVID-19. Art Educ. 2021, 74, 10-12. [CrossRef]

107. Pascoal, S.; Tallone, L.; Furtado, M. The Impact of COVID-19 on Cultural Tourism: Virtual Exhibitions, Technology and Innovation. In Proceedings of the International Conference on Tourism, Technology and Systems, Cartagena, Colombia, 29-31 October 2020; pp. 177-185.

108. Cecilia, R.R. COVID-19 Pandemic: Threat or Opportunity for Blind and Partially Sighted Museum Visitors? J. Conserv. Mus. Stud. 2021, 19. [CrossRef]

109. Inayatullah, S. Future Avoiders, Migrants and Natives. J. Future Stud. 2004, 9, 83-86.

110. Canning, S.; Spennemann, D.H.R. Contested space: Social value and the assessment of cultural significance in New South Wales, Australia. In Heritage Landscapes: Understanding Place and Communities; Cotter, M.M., Boyd, W.E., Gardiner, J.E., Eds.; Southern Cross University Press: Lismore, NSW, Australia, 2001; pp. 457-468.

111. Kerr, J.S. The Conservation Plan: A Guide to the Preparation of Conservation Plans for Places of European Cultural Significance; National Trust of Australia: Sydney, NSW, Australia, 1985.

112. Johnston, C. What Is Social Value?: A Discussion Paper; Australian Government Publishing Service: Canberra, ACT, Australia, 1992.

113. Jones, S. Wrestling with the Social Value of Heritage: Problems, Dilemmas and Opportunities. J. Community Archaeol. Herit. 2017, 4, 21-37. [CrossRef]

114. Waterton, E.; Smith, L. The recognition and misrecognition of community heritage. Int. J. Her. Stud. 2010, 16, 4-15. [CrossRef]

115. English Heritage. Regeneration and the Historic Environment: Heritage as a Catalyst for Better Social and Economic Regeneration; English Heritage: London, UK, 2005.

116. Spennemann, D.H.R. An Integrated Architecture for successful Heritage Site Management Planning. CRM J. Herit. Steward. 2007, 4, 18-28.

117. Graham, K.; Spennemann, D.H.R. Heritage managers and their Attitudes towards Disaster Management for cultural heritage resources in New South Wales, Australia. Int. J. Emerg. Manag. 2006, 3, 215-237. [CrossRef]

118. Laidlaw, P.; Spennemann, D.H.R.; Allen, C. Protecting cultural assets from bushfires: A question of comprehensive planning. Disasters 2008, 32, 66-81. [CrossRef] [PubMed]

119. Spenneman, D.; Lockwood, M.; Harris, K. The eye of the professional vs. opinion of the community. CRM 2001, $24,16-18$.

120. Spennemann, D.H.R. The Day the Mouse Could Roar. Considering the role of the Silent Majority in Historic Preservation. Keynote Paper read at the International Luncheon. In Proceedings of the 30th Annual California Preservation Conference, Riverside, CA, USA, 13 May 2005; pp. 1-24.

121. Spennemann, D.H.R. Futurist rhetoric in U.S. historic preservation: A review of current practice. Int. Rev. Public Nonprofit Mark. 2007, 4, 91-99.

122. Spennemann, D.H.R. The Futurist Stance of Historical Societies: An analysis of positioning statements. Int. J. Arts Manag. 2007, 9, 4-15.

123. Spennemann, D.H.R. The Public Manifestation of the Futurist Stance of Historic Preservation. A Rapid Appraisal of the World-Wide Web; Institute for Land, Water and Society, Charles Sturt University: Albury, NSW, Australia, 2006.

124. Ashworth, G.J. Conservation as Preservation or as Heritage: Two Paradigms and Two Answers. Built Environ. 1997, $23,92-102$.

125. Janssen, J. Modernising Dutch Heritage Conservation: Current Progress and Ongoing Challenges for Heritage-Based Planning and Management. Tijdschr. Voor Econ. Soc. Geogr. 2014, 105, 622-629. [CrossRef]

126. Velthuis, K.; Spennemann, D.H.R. The future of Defunct Religious Buildings: Dutch Approaches to their Adaptive Reuse. Cult. Trends 2007, 16, 43-66. [CrossRef] 